\title{
Tissue Engineering Craniofacial Defects With Adult Stem Cells? Are We Ready Yet?
}

\author{
PATRICIA A. ZUK
}

Department of Surgery, David Geffen School of Medicine, The University of California at Los Angeles, Los Angeles, California 10833

\begin{abstract}
Over three-quarters of all craniofacial defects observed in the US per year are cleft palates. Usually involving significant bony defects in both the hard palate and alveolar process of the maxilla, repair of these defects is typically performed surgically using autologous bone grafts taken from appropriate sites (i.e., iliac crest). However, surgical intervention is not without its complications. As such, the reconstructive surgeon has turned to the scientist and engineer for help. In this review, the application of the field of tissue engineering to craniofacial defects (e.g., cleft palates) is discussed. Specifically the use of adult stem cells, such as mesenchymal stem cells from bone marrow and Adipose-derived Stem Cells (ASCs) in combination with currently available biomaterials is presented in the context of healing craniofacial defects like the cleft palate. Finally, future directions with regards to the use of ASCs in craniofacial repair are discussed, including possible scaffold-driven and gene-driven approaches. (Pediatr Res 63: 478-486, 2008)
\end{abstract}

$\mathrm{A}^{1}$ t $75 \%$ of all birth defects recorded in the US per year, craniofacial defects, such as cleft palate, are the most common birth defect affecting nearly 225,000 children each year (1). Correction of many of these defects requires extensive surgical intervention using bone-grafting techniques and will often involve numerous procedures over the course of at least a decade. To the child, bone grafting requires extensive healing time-at both the correction site and donor site, runs the risk of infection, results in significant amounts of pain, and does not guarantee complete correction of the defect if the graft fails to integrate within the surgical site. Beyond the child, surgical correction of such craniofacial defects also places a huge emotional and financial burden on the child's family and ultimately places a financial burden on the US health care system. In 2001, data from the US Health Cost and Utilization Project reported that 12,700 cranial bone grafts were performed to repair craniofacial defects in children at a cost of over $\$ 549$ million (2). As such, there has been a call for alternate approaches that, at a minimum, can decrease the severity of the many side effects associated with surgery. Although the complete elimination of surgery is unrealistic, the creation of cutting edge technologies may decrease the number of procedures and ultimately improve the final outcome of the necessary surgeries. One such cutting-edge technology may be the stem cell.

Received November 6, 2007; accepted December 20, 2007.

Correspondence: Patricia Zuk, PhD, The University of California at Los Angeles, David Geffen School of Medicine, Department of Surgery, 10833 LeConte Ave, Los Angeles, CA 90095; e-mail: zukpat@yahoo.com

\section{THE CLEFT PALATE}

Of all the possible craniofacial defects observed in newborns, perhaps the most well-known defect is the cleft palate. Occurring with a frequency of approximately 1 in every 700 per year in the US, the incidence of cleft palate equates to 475 cleft palates per month or 15 clefts per day (3). The layman's term "cleft palate" is actually a combination of soft and hard tissue defects involving the lip and maxilla. Although clefting of the lip only can occur (i.e., cleft lip), it is most often accompanied by a cleft within the palate (i.e., cleft lip with palate). With respect to the maxilla, two main regions are often involved in the cleft palate: 1) the primary palate-the region of the palate anterior to the incisive foramen and 2) the secondary palate- the region of the palate posterior to this foramen. Clefts in the primary palate involving the alveolar process and the lip are referred to as primary palate clefts, whereas clefting in the secondary palate involving just the hard and/or soft palate are termed secondary clefts. More commonly, clefts involve both palates and are referred to as complete cleft palates. These possible clefts can form on one side of the facial midline- unilateral clefts- or can form on both sides-bilateral clefts.

Embryologically, development of the face begins at the fourth week with the migration of neural crest cells toward the head region and their combination with core mesoderm and epithelial cells to become the facial primordia. Within these primordia, mesenchymal tissue derived from neural crest cells will become the facial skeleton with the mesenchymal cells derived from the mesoderm forming the facial musculature $(4,5)$. At $24 \mathrm{~d}$, the primitive mouth forms (stomatodeum) along with the mandibular arch or first pharyngeal arch. Just 2 days later, this stomatodeum is surrounded by five primordia comprised of an unpaired frontonasal prominence, a pair of maxillary processes and a pair of mandibular processes. At $32 \mathrm{~d}$, a thickening of the surface epithelium in the frontonasal prominence produces nasal placodes that become surrounded by the horseshoe-shaped nasal processes (lateral and medial). Growth of the maxillary and medial nasal processes (MNP) pushes the lateral nasal process up and brings the maxillary process and MNP into contact- events that are critical to the

Abbreviations: ASCs, Adipose-derived Stem Cells; BMP2, bone morphogenic protein 2; DMB, demineralized bone matrix; ES cell, embryonic stem cell; HA, hydroxyapatite; MNP, medial nasal process; MSC, Mesenchymal Stem Cell; PLGA, poly(lactic-co-glycolic) acid; SVF, stromo-vascular fraction; TCP, tri-calcium phosphate 
formation of a continuous upper lip (6). Following contact and fusion, the MNP develops into the intermaxillary segment that will form the central portion of the lip and contributes to palate formation. Outgrowths of this segment into the oral cavity and their fusion forms the anterior or primary palate, whereas the maxillary processes give rise to lateral palatal shelves (7) that fuse to form the posterior or secondary palate. Failure of the intermaxillary outgrowths to fuse results in primary palate clefts with failure of the maxillary processes to fuse producing the secondary cleft. Failure of both of these fusion events results in a unilateral or bilateral complete cleft palate. Because the formation of the lip occurs before development of the palate, it is easy to recognize that most palate defects are accompanied by clefting of the lip. Therefore, the term cleft lip with palate is frequently termed just cleft palate.

Cleft lips and palates have both functional and esthetic implications for children. Functionally, midfacial skeletal growth is affected dramatically by the failure of the facial processes to fuse properly and dramatic alterations to the face, including proper alignment of teeth, can occur. Such malformations can result in social alienation of the child because he or she "looks funny." The development of speech can also be profoundly affected along with increased incidence of ear infections owing to improper draining of the middle ear. In the infant, the cleft can prevent the child from developing normal suction during suckling, thus eliminating the choice of breastfeeding. At the everyday level, the malformed palate necessitates the purchase of specialized bottles that help deliver milk to the back of the throat, where it can be swallowed normally. It becomes easy to see that correction of craniofacial defects like the cleft palate represents a tremendous leap forward in the medical field.

Close to 600,000 bone grafts are performed in the US each year with approximately $6 \%$ of these grafts craniofacial in nature (8). To the surgeon, repair of the cleft palate is imperative as it provides bony continuity and stability to the alveolar ridge, allowing for proper tooth movement and eruption, provides support to the lip and nose and closes the oronasal fistula. To the family, repair of the defect dramatically improves the quality of life for the child. The earliest repairs of palates were performed by suturing the palatal halves together but were immobile and dramatically impacted the speech and swallowing of the patient. Repair of the alveolar portion of the cleft has been even more complicated. Although initial closure of the lip and palate can easily be performed within the first 6 mo, most patients will require secondary bone grafts over the next decade to correct the growing alveolar portion of the mandible. Add to this, the need to consider tooth eruption and alignment and the reconstruction of a cleft palate becomes extremely complicated. Current reconstructive techniques combine the advantages of prosthetic, allogeneic and autologous (i.e., bone grafts) materials. In the last $50 \mathrm{y}$, bone grafting of the alveolar cleft defect using autologous cancellous bone grafts has become the gold standard for reconstruction because of their osteoconductive and osteoinductive properties. However, these properties do not necessarily guarantee success as the graft may not fully integrate into the host bone and may undergo a certain level of resorption. Add to this donor site morbidity, disease transmission and contour irregularities and the craniofacial surgeon faces a significant challenge in the treatment of the cleft palate (9). To solve these problems, the physician has turned to both the scientist and engineer.

\section{CRANIOFACIAL DEFECTS AND TISSUE ENGINEERING-A MATCH MADE IN HEAVEN?}

Tissue engineering can be simply defined as the regeneration of new tissues through the combined use of biomaterials and biologic mediators, such as the stem cell. In the field of orthopedics, tissue engineering applications have grown in popularity with numerous studies reporting the healing of long bone and calvarial defects in numerous large and small animal models. However, the application of tissue engineering to craniofacial defects may be more challenging. Simply put, the implanted construct within the craniofacial defect would be under tremendous strain and stress. Numerous studies have examined the magnitude and direction of strain and stress in several long-bone defect models and have begun to develop computer-modeling systems that help the bioengineer understand the mechanical environment within the bone. Unfortunately, understanding the physical environment within the skull does not appear to be as straightforward (for review see (10)). Although not intuitively obvious, the bones of craniofacial arena are under significant amounts of stress-mostly provided by the large muscles of mastication (e.g., masseter). Recent large animal studies have found it difficult to reliably put a "number" to the mechanical loads found within the human skull $(11,12)$, making the design of the "perfect" craniofacial implant for tissue engineering a significant challenge.

\section{CRANIOFACIAL TISSUE ENGINEERING}

\section{Pick a Scaffold, Any Scaffold}

To the craniofacial reconstructive surgeon, tissue engineering advancements over the last decade has provided a plethora of materials that may be suitable for the healing of craniofacial defects like the cleft palate. At a basic level, tissue engineering scaffolds can be broken down into three groups: autografts, allografts, and xenografts. Today the reconstructive surgeon makes best use of the autograft category, taking bone from another site (e.g., iliac crest, rib) and transplanting it into the cleft defect. With the disadvantages of host-site morbidity and a lack of suitable graft sites and material, the use of xenografts-i.e., bone grafts from animals-would be a good fit. Of course, it is obvious that histocompatability issues between the human patient and the animal donor would preclude its use. In fact, xenografts are not currently allowed in the United States. This leaves the allograft.

As a category, allografts can be organized into two groups: natural and synthetics.

Natural. The natural category is a broad-range category that includes bone powders, chips and fragments. Processed to remove the cellular components, natural materials are osteoconductive but poorly osteoinductive, thus decreasing the robustness of the response versus a conventional autograft (13). An alternate natural allograft is demineralized bone 
matrix (DMB), the decellularized, organic component of bone. DMB represents a concentrated source of BMPs and has been used in numerous animals systems since its initial description in 1965 (14). Available commercially from tissue banks, the widespread use of DMB in humans still remains restricted as the immunologic properties of donor DMB is unknown.

Synthetic. As an alternative to natural scaffolds, the reconstructive surgeon has available a wide variety of synthetic scaffolds, including ceramics, calcium phosphates and polymers (Table 1). Ceramics [often referred to as hydroxyapatites (HAs)] are a family of calcium phosphate and calcium sulfate materials with a diverse spectrum of mechanical and degradative properties based on their composition and processing (15). Meant to be a substitute for the mineral phase of bone, ceramics are purely osteoconductive but can be combined with stem cells (i.e., marrow) to provide osteogenic potential $(15,16)$ Moreover, degradation in vivo can easily be affected by changing parameters such as their calcium to phosphate ratio or their internal surface area (i.e., pore architecture). Similar to ceramics, calcium phosphates are a general term for a large group of scaffold compositions many of which are commercially available today as $\beta$-tricalcium phosphate/TCP, or biphasic calcium phosphates (e.g., HA in combination with TCP or HA/TCP). All try to closely match the calcium to phosphate ratio of natural HA and possess excellent bonebonding ability. Originally used over $20 \mathrm{y}$ ago as coralline HA implants (17), many forms of calcium phosphate scaffolds are used today in orthopedic surgery and have been described extensively elsewhere (18-20) Some calcium phosphates are currently in use clinically repairing cranial defects in the form of calcium phosphate "cements"-a wet paste that can be applied to irregular bony defects and allowed to "cure" thus forming HA $(21,22)$. Such scaffolds would have the advantage of filling the irregular contours of a craniofacial defect. However, the combination of these cements with stem cells has not

Table 1. Synthetic Bone Engineering Composites

\begin{tabular}{ll}
\hline \multicolumn{1}{c}{ Scaffold type } & Commercial name \\
\hline Chitosan (poly-1,4-D-glucosamine) & \\
Ceramics & \\
Hydroxyapatite/HA & \\
Sintered HA & \\
Biomimetic HA & e.g., Cellplex \\
Bioglass & \\
Calcium phosphates & \\
$\beta$-Tricalcium phosphates & \\
Biphasic calcium phosphates (e.g. HA/TCP) & \\
Synthetic polymers & e.g., Healos \\
Poly(lactic-co-glycolic) acid & \\
Poly-L-lactic acid & e.g., Collagraft \\
CNI-HA & e.g., Ceraform \\
Treated metals-titanium, tantalite & \\
Composites & \\
CNI/ $\beta$-TCP, CNI /HA & \\
PLA/HA/CNI sponges & \\
PLGA/HA & \\
Gelatin/chitosan & \\
PLA/chitosan &
\end{tabular}

CNI, collagen type I; HA, hydroxyapatite; PLA, poly-L -lactic acid; PLGA, poly(lactic-co-glycolic) acid; TCP, tricalcium phosphate. been fully explored. Finally, many studies now employ the use of organic synthetic scaffolds based on alpha-hydroxy acids $(23,24)$. These scaffolds are usually composed of polyglycolic acid, poly-L-lactic acid or a combination of both (i.e., PLGA) possess limited osteoconductive capacity but when combined with HA technologies become excellent materials for bone repair by stem cells. The last 10 years has seen additions to this large field with the development of scaffolds comprised of a variety of materials including polyvinyl, polycaprolactone, and polyhydroxyalkanoate. Again, too large of a field to adequately review here, numerous excellent reviews detail the use of these organic polymers with and without combination with calcium phosphates and ceramics $(25,26)$.

\section{Adult Stem Cells-The List Keeps Growing and Growing}

Today, multiple sources for the isolation of adult stem cells have been identified, including heart tissue (27), umbilical cord blood (28), skeletal muscle $(29,30)$, and the dermis of skin (31). But, to the craniofacial surgeon interested in using tissue engineering, there are two exciting sources of stem cells: bone marrow and adipose tissue.

Mesenchymal stem cells (MSCs). The identification of pluripotent MSCs in the bone marrow stroma over $25 \mathrm{y}$ ago (32) has led researchers to a variety of exciting research avenues. Capable of differentiating to multiple mesodermal lineages, including bone and cartilage, MSCs have become a standard in the field of adult stem cell biology and in regenerative medicine (33-38). So, it is only natural that these stem cells would be used in the repair of significant bony defects caused by trauma, surgery, or disease. Consistent with this, multiple studies have reported the formation of bone tissue both in vitro and in vivo upon the combination of MSCs and 3D scaffold supports. In vitro, a wide spectrum of scaffolds are being combined with MSCs, including, HA/chitosan composites, chitosan or gelatin/TCP constructs, electrospun collagen nanofibers, honeycomb collagen scaffolds, and titanium meshes (39-44). In animals, the scaffolds and model systems used have varied from HA ceramics or HA/TCP constructs for the healing of small bone defects in rodents or larger defects in dogs, rabbits, or sheep (45-49), to complicated biosynthetic composites $(50,51)$, to silk-based biomaterials in the healing of segmental femoral defects in nude mice (52). Each of these studies report encouraging results and espouse the use of bone marrow MSCs in the repair of bony defects.

Adipose-derived stem cells. Historically, the adipose compartment has been considered primarily a metabolic reservoir-effectively packaging, storing, and releasing highenergy substrates in the forms of triglycerides and cholesterol as well as lipid-soluble vitamins. However today, the adipose compartment may be a site for an abundant population of stem cells-the adipose-derived stem cell (ASC) $(53,54)$. Like the bone marrow, adipose tissue contains an extensive cellular stroma comprised of fibroblastic-like cells termed by Rodbell in 1964 as the stromo-vascular fraction or SVF (55). Further work by Hauner expanded this knowledge and postulated that the preadipocytes within the SVF represented a "progenitor" 
population, though apparently limited to the adipocytic lineage (56). However, in 2001, Zuk et al. showed that the SVF fraction isolated from human lipoaspirates in fact contained cells with multilineage potential and termed these cells processed lipoaspirate cells $(53,54)$. Now renamed ASCs (57), these cells undergo adipogenesis, osteogenesis, chondrogenesis, and myogenesis in vitro, suggesting that the SVF fraction of adipose tissue may, in fact, be comprised not just of lineage limited preadipocytes but of multipotent stem cells. Since their initial characterization only $6 \mathrm{y}$ ago, the amount of work performed determining the multipotentiality of the ASC population has been staggering $(53,54,58-81)$. Numerous articles not only continue to document the mesodermal potential of these stem cells but now suggest expanded germ-layer potential by describing their ability to form putative neurons, hepatocytes and pancreatic cells - at least in vitro $(63,65,66)$. Today, the researcher interested in ASCs has a wide variety of review articles from which to learn of these cells $(57,82-85)$.

ASCs have also become a hot topic in the world of tissue engineering. Numerous studies have begun to explore the osteogenic potential of ASCs in vivo through their combination with a wide variety of scaffolding materials. Groups led by Lee and Hicok were the first to show that s.c. implantation of human ASCs loaded onto HA/TCP or polyglycolic scaffolds could result in the formation of an osteoid-like material $(86,87)$. Subsequent studies have since attempted to confirm this finding in established animal models with limited amounts of success $(86,88-90)$. To improve their ability to form bone, many of these studies treat ASCs with the osteogenic growth factor BMP2. Both Peterson and Dragoo were the first to describe the engineering of well-formed bone by ASCs in athymic rodents with the help of bone morphogenic protein 2 (BMP2) $(88,89,91)$ and several MSC studies have shown that this osteogenic factor can be used in concert with these stem cells also (92-94). Many of these studies claim that increased bone formation can be attributed to the presence of BMP2treated ASCs. However, the greater majority of these works fail to report levels of healing when empty scaffolds treated with BMP2 were used as controls. Many studies fail to use this construct as a control at all. This omission makes it difficult to determine whether the ASC itself is responsible for the bony healing or if the healing can be attributed to the powerful osteoconductive and osteoinductive effects of BMP2. As such, future studies will be needed to specifically determine the true osteogenic capacity of ASCs without their combination with growth factors.

\section{Craniofacial Engineering Using Stem Cells-The Story So Far}

Today's scientific literature seems to detail a litany of exciting studies in which embryonic stem (ES) cells can integrate and heal damaged tissues in both animal and human model systems. Although ES cells are known to form bone, the raging ethical debate surrounding these stem cells will likely make their use in craniofacial procedures all but impossible. As such, the reconstructive surgeon is compelled to look elsewhere for help. The most obvious option has become the
MSC from bone marrow. Recently, the use of isolated and expanded MSCs has become more and more popular in the literature. To list a few, MSCs have been combined with HA/TCP scaffolds to help build calvarial and alveolar bone in dogs $(95,96)$, loaded onto gelatin sponges for the repair of calvarial defects in mice (97), combined with polycaprolactone-based scaffolds to repair cranial defects in rabbits (98) and seeded into hyaluronan based polymers for reconstruction of orbital rim defects in pigs (99). Osteo-induced MSCs have also been combined with calcium alginate composites to repair alveolar defects in dogs (100) and cranial defects in sheep (101). Although freeze-dried bone marrow has long been used in the repair of human alveolar clefts (for review see Ref. 102), the use of purified MSCs in cleft repairs is still rare in clinical studies. However, MSCs have recently been combined with platelet-rich plasma to heal an alveolar cleft in a 9-yr-old girl (103). As scaffolds suitable for repairing cleft defects become more available, these studies will surely increase in number.

Although the MSC continues to be viable option for a stem cell population in craniofacial repair, there are drawbacks to the population that must be recognized. Foremost is the pain and stigma associated with the bone marrow harvest. Second is the yield. Although MSCs grow well under standard tissue culture conditions, ex vivo amplification is a necessity due to relatively low numbers of MSCs thought to be present in the harvested marrow (1 MSC/ $10^{4}-10^{6}$ stromal cells (104)). In light of this, adipose tissue has become an extremely attractive option. In fact, the use of the buccal fat pad in the reconstruction of soft palate, maxillary defects, and palatal clefts has been used for several years in clinical studies with varying results $(105,106)$. Descriptions of purified ASCs in craniofacial engineering appear to be limited in today's literature and their use has also resulted in varying amounts of success. For example, the implantation of osteoinduced rabbit ASCs and gelfoam scaffolds into rabbit calvarial defects did not significantly improve bony healing when compared with controls (107). In contrast, Yoon and colleagues report improved calvarial defect healing upon implantation of PLGA scaffolds seeded with human ASCs maintained in vitro in the presence of osteogenic factors before implantation (108). However, the improved bone formation they observed was compared with ASC/PLGA scaffolds maintained in vitro in noninductive DMEM. It remains unreported whether acellular scaffolds maintained in osteogenic media were performed as a control or if they produced similar levels of healing as the ASC-seeded scaffolds preinduced toward the osteogenic lineage. Therefore it is difficult to determine whether the healing was due to the activity of the ASC or osteo-inductive factors absorbed to the scaffold. Today, numerous alternatives to conventional HA or polymers are being proposed as supports for the repair of large bony defects using ASCs, including silk-fibrin grafts not unlike those used with MSCs (109), coral matrices (110), or decellularized bone tubes (111).

Yet, despite all this apparent progress, the application of tissue engineering techniques specifically to palatal bone engineering has been limited and progress slow. Repair of palatal defects caused by nonfusion has been performed in 
vitro using embryonic mesenchyme tissue (112), whereas the insertion of BMP2-coated heparin beads has been found to promote the in vitro fusion of small fragments of human palate with its murine host (113). Work in the veterinary field suggests that MSCs may be used to heal soft palate defects in horses (114). Recently, one study by Conejero and coworkers has emerged to suggest that the ASC is being closely examined for its applicability to craniofacial defects, like cleft palate. In this study, rat ASCs were seeded onto conventional poly-L-lactic acid scaffolds and induced in osteogenic medium for $7 \mathrm{~d}$ before being inserted into surgically produced cleft defects. The researchers reported significant bone formation in the palates treated with osteogenically differentiated ASCs. However, like the studies of Yoon, which were similar in composition, these authors also fail to report if acellular scaffold controls treated for 1 week in osteogenic medium also healed palates to any degree. Despite this, the application of ASCs to palate defect models and their putative ability to treat these defects is an exciting development.

\section{WHERE DO WE GO FROM HERE?}

Several animal models have induced bone formation within long bone and cranial defects by using MSCs treated with or virally-expressing BMP2 (92,94,115-118). Based on the early work of Peterson and Dragoo $(88,89,91)$, it is not unreasonable to think that ASCs, treated with BMP2, would be capable of forming bone within a cleft defect. However, work by Leboy has suggested that BMP2 may not promote osteogenic differentiation of human MSCs $(119,120)$. Similarly, in patients receiving recombinant $\mathrm{BMP} 2$ treatment, the regenerative response is several times lower than that previously measured in animal studies (121), suggesting that the response of human cells to BMP2 may not be directly comparable to that observed by animal cells. Although several studies have begun to combine BMP2 and ASCs, surprisingly, to date, no in-depth in vitro studies have been performed to confirm if BMP2 can actually promote ASC osteogenesis. Like human MSCs, it is possible that BMP2 has no effect on inducing ASC-driven bone formation (Zuk, unpublished observations). In addition, it remains unknown the effect of such a powerful growth factor as BMP2 would have on the craniofacial arena in very young children. The question becomes how do we augment the ability of an adult stem cell, like the ASC, to make large quantities of bone within a craniofacial defect like a cleft palate without such growth factors? Promising results may be linked to three distinct approaches or a combination of them.

\section{The "Scaffold-Driven" Approach-Biomimetic Apatites}

Efficient use of 3D scaffold systems in bone repair is dependent upon their bond-bonding or bioactive ability. Although scaffolds such as PLGA or PLA composites provide the reconstructive surgeon with a biodegradable platform for stem cell adhesion and differentiation, their bioactivity can be limited. However, studies have suggested that their bioactivity can be strengthened through the formation of a layer of HA at the bone-implant interface $(122,123)$. Several HA materials for use in bone differentiation have been developed within the last 20 years and are thought to possess superior in vivo bioactivity. However, much excitement has been generated regarding the osteoinductive capacities of biomimetic apatite coatings. Typically created through the immersion of $3 \mathrm{D}$ scaffolds in ionic solutions with compositions similar to blood plasma_called Simulated Body Fluids_-biomimetic apatites are composed of plate-like crystals of calcium phosphate capable of coating the entire 3D scaffold architecture $(124,125)$. An improvement on biomimetic apatites has recently been presented by $\mathrm{Wu}$ and colleagues through their development of accelerated biomimetic approaches that dramatically shorten the time required for coating from approximately 2 weeks to 2 days $(126,127)$. Such convenience may make the accelerated biomimetic apatite more attractive for in vivo applications such as bone healing. In support of this, accelerated apatite coatings have been shown by $\mathrm{Wu}$ and his group to promote bone in-growth and differentiation of preosteoblasts and bone marrow stem cells and to enhance direct bone to bone contact (125). Recently, accelerated apatites have also been shown to promote the osteogenic capacity of ASCs. In a landmark paper by Cowan et al., murine ASCs seeded onto accelerated apatite coated PLGA scaffolds were found to heal critical-sized cranial defects without the need for exogenous stimulation such as BMP2 treatment (128). Although the ASCs used were murine and no further studies using human ASCs have been presented, these results remain exciting because they show the reconstructive surgeon that methods other than conventional growth factor stimulation may be used to induce stem cells to make and heal bone.

\section{The "Cell-Driven" Approach-The Pediatric Stem Cell}

Despite all that we know of the adult stem cell, we still know very little about how their age affects their differentiative capacity. The use of a pediatric stem cells in the repair of craniofacial defects should be intuitive since repair of the defect would require the child's own stem cell. With regards to the ASC, it would be relatively simple for the craniofacial surgeon to extract a small amount of adipose tissue from the child using a simple syringe. This could easily be done during one of the many preparatory procedures that often precedes major craniofacial reconstruction. These pediatric ASCs (pedASCs, i.e., under 5 y) could be expanded in the lab and combined with the best possible scaffold for implantation into the defect. Yet, there is no current information available that studies pedASCs at an in-depth level.

\section{The "Gene-Driven" Approach-Molecular Signaling Within the Stem Cell}

Although the adult stem cell researcher has learned much of the ultimate downstream genes involved in bone differentiation (i.e., Runx2/Cbfa1, Osterix), we are only beginning to understand the upstream mechanisms that control them. $\mathrm{Nu}$ merous studies have elucidated possible signaling pathways downstream of BMP2 induction and how these pathways may affect osteogenic gene transcription (129-131). However, it is possible that osteogenesis in $\mathrm{ASCs}$ is under an alternate 
signaling pathway. In fact, very little is known about signal transduction pathways in adult stem cells like ASCs. Jaiswal et al. (132) have examined the role of MEK-ERK signaling in deciding adipogenic and osteogenic fates in MSCs. ERK pathways and there role in obesity and adipogenesis have been examined in ASCs along with the role of MAPK signaling in ASC proliferation, migration, and apoptosis (133-135). However, the number of these studies does appear to be increasing as researchers turn to gene therapy approaches in the hopes of understanding and alleviating the disease state. For example, significant bone regeneration in a rabbit calvarial model has been measured upon implantation of MSCs transduced with Sonic Hedgehog (Shh) — a key protein involved in craniofacial morphogenesis (136). Although these results are promising, the stem cell population must be carefully considered as Shhexpressing ASCs were capable of regenerating bone within a calvarial defect but also appeared to induce the formation of large cyst-like structures. Canonical and noncanonical Wnt signaling pathways have also come under focus because of their wellknown role as regulators of embryologic patterning, stem cell fate and mesenchymal differentiation (137). Observations linking the LRP5 gene mutation and osteoporosis-pseudoglioma syndrome have suggested a connection between Wnt signaling and bone formation (138). Consistent with this, work in MSCs has linked Wnt3a induced signaling to a suppression of bone formation in vitro and in vivo (139). In contrast, increased bone regeneration in both mandibular and calvarial defects has been observed in MSCs isolated from craniofacial tissues overexpressing Wnt4 (140). Analysis of these Wnt4-transduced MSCs identified a specific increase in p38MAPK phosphorylation suggesting that increased activity of this MAPK kinase may act to promote MSC-driven bone formation within the defect. Similar to this, microarray analysis of developing orofacial tissues has identified the differential expression of a number of MAPK pathway genes, suggesting that this pathway may play a role in craniofacial development (141). Together, these studies suggest that stem cell-directed bone within craniofacial defects might be augmented not through upstream growth factors but through the careful and directed manipulation of their downstream signaling paths. Finally, in stem cells like MSCs, adhesion significantly affects osteogenic differentiation with differential effects being attributed to the actual substrate (142). This effect is likely to be controlled at many levels including interactions between the substrate and integrin complexes $(143,144)$. Because numerous signaling pathways, including the MAPK cascade, can be induced through integrin-matrix interactions in a variety of cells (145), it is not unreasonable to hypothesize the design of scaffolds that mimic the effect of growth factors through adhesion-based mechanisms, mediating signaling through specific "pro-osteogenic" signal transduction pathways.

\section{"State of the Field"-A "Call to Arms" to the Adult Stem Cell Researcher}

It seems like everyday we read about huge advances in the field of ES research detailing daring approaches in the application of these stem cells to the clinical world. The question is where is the adult stem cell researcher? True advances in the medical and scientific world using adult stem cells like the ASC will not be achieved by playing it "safe." In the modern marketing world, we hear phrases like "kick it up a notch" and "think outside the box." The adult stem cell researcher needs to take these phrases to heart and look outside conventional fields for inspiration and knowledge. The combination of the stem cell researcher with the biomaterials engineer has been an example on how what appears to be an unconventional collaboration can advance the scientific community and benefit the general public. Who knows where these relationships will take us? But one thing is for sure-collaboration brings people together who look at the world in different ways. From these unions, we can propel the fields of adult stem cell biology and craniofacial tissue engineering into a whole new realm-where all things are possible.

\section{REFERENCES}

1. Vanderas AP 1987 Incidence of cleft lip, cleft palate, and cleft lip and palate among races: a review. Cleft Palate J 24:216-225

2. Steiner C, Elixhauser A, Schnaier J 2002 The healthcare cost and utilization project: an overview. Eff Clin Pract 5:143-151

3. Witt PD, Marsh JL 1998 Cleft Palate Deformities. Stamford, CT: Appleton \& Lange.

4. Couly GF, Coltey PM, Le Douarin NM 1992 The developmental fate of the cephalic mesoderm in quail-chick chimeras. Development 114:1-15

5. Noden DM 1982 Patterns and organization of craniofacial skeletogenic and myogenic mesenchyme: a perspective. Prog Clin Biol Res 101:167-203

6. Trasler DG 1968 Pathogenesis of cleft lip and its relation to embryonic face shape in A-J and C57BL mice. Teratology 1:33-49

7. Ferguson MW 1988 Palate development. Development 103:41-60

8. Greenwald AS, Boden SD, Goldberg VM, Khan Y, Laurencin CT, Rosier RN 2001 Bone-graft substitutes: facts, fictions, and applications. J Bone Joint Surg Am 83-A:98-103

9. Mulliken JB, Glowacki J 1980 Induced osteogenesis for repair and construction in the craniofacial region. Plast Reconstr Surg 65:553-560

10. Herring SW, Ochareon P 2005 Bone-special problems of the craniofacial region. Orthod Craniofac Res 8:174-182

11. Hylander WL, Johnson KR 1997 In vivo bone strain patterns in the zygomatic arch of macaques and the significance of these patterns for functional interpretations of craniofacial form. Am J Phys Anthropol 102:203-232

12. Teng S, Herring SW 1996 Anatomic and directional variation in the mechanical properties of the mandibular condyle in pigs. J Dent Res 75:1842-1850

13. Stevenson S 1998 Enhancement of fracture healing with autogenous and allogeneic bone grafts. Clin Orthop Relat Res S239-S246

14. Urist MR 1965 Bone: formation by autoinduction. Science 150:893-899

15. LeGeros RZ 2002 Properties of osteoconductive biomaterials: calcium phosphates. Clin Orthop Relat Res 81-98

16. Ohgushi H, Dohi Y, Tamai S, Tabata S 1993 Osteogenic differentiation of marrow stromal stem cells in porous hydroxyapatite ceramics. J Biomed Mater Res 27:1401-1407

17. Kuhne JH, Bartl R, Frisch B, Hammer C, Jansson V, Zimmer M 1994 Bone formation in coralline hydroxyapatite. Effects of pore size studied in rabbits. Acta Orthop Scand 65:246-252

18. Ohgushi H, Okumura M, Tamai S, Shors EC, Caplan AI 1990 Marrow cell induced osteogenesis in porous hydroxyapatite and tricalcium phosphate: a comparative histomorphometric study of ectopic bone formation. J Biomed Mater Res 24:15631570

19. Toquet J, Rohanizadeh R, Guicheux J, Couillaud S, Passuti N, Daculsi G, Heymann D 1999 Osteogenic potential in vitro of human bone marrow cells cultured on macroporous biphasic calcium phosphate ceramic. J Biomed Mater Res 44:98-108

20. Ioku K, Yanagisawa K, Yamasaki N, Kurosawa H, Shibuya K, Yokozeki H 1993 Preparation and characterization of porous apatite ceramics coated with betatricalcium phosphate. Biomed Mater Eng 3:137-145

21. Goodman SB, Bauer TW, Carter D, Casteleyn PP, Goldstein SA, Kyle RF, Larsson S, Stankewich CJ, Swiontkowski MF, Tencer AF, Yetkinler DN, Poser RD 1998 Norian SRS cement augmentation in hip fracture treatment. Laboratory and initial clinical results. Clin Orthop Relat Res: 42-50

22. Eppley BL, Hollier L, Stal S 2003 Hydroxyapatite cranioplasty: 2. Clinical experience with a new quick-setting material. J Craniofac Surg 14:209-214

23. Coombes AG, Meikle MC 1994 Resorbable synthetic polymers as replacements for bone graft. Clin Mater 17:35-67

24. Freed LE, Vunjak-Novakovic G, Biron RJ, Eagles DB, Lesnoy DC, Barlow SK, Langer R 1994 Biodegradable polymer scaffolds for tissue engineering. Biotechnology (NY) 12:689-693 
25. Abukawa H, Papadaki M, Abulikemu M, Leaf J, Vacanti JP, Kaban LB, Troulis MJ 2006 The engineering of craniofacial tissues in the laboratory: a review of biomaterials for scaffolds and implant coatings. Dent Clin North Am 50:205-216.

26. Eppley BL, Pietrzak WS, Blanton MW 2005 Allograft and alloplastic bone substitutes: a review of science and technology for the craniomaxillofacial surgeon. J Craniofac Surg 16:981-989

27. Warejcka DJ, Harvey R, Taylor BJ, Young HE, Lucas PA 1996 A population of cells isolated from rat heart capable of differentiating into several mesodermal phenotypes. J Surg Res 62:233-242

28. Campagnoli C, Roberts IA, Kumar S, Bennett PR, Bellantuono I, Fisk NM 2001 Identification of mesenchymal stem/progenitor cells in human first-trimester fetal blood, liver, and bone marrow. Blood 98:2396-2402

29. Nöth U, Tuli R, Osyczka AM, Danielson KG, Tuan RS 2002 In vitro engineered cartilage constructs produced by press-coating biodegradable polymer with human mesenchymal stem cells. Tissue Eng 8:131-144

30. Wada MR, Inagawa-Ogashiwa M, Shimizu S, Yasumoto S, Hashimoto N 2002 Generation of different fates from multipotent muscle stem cells. Development 129:2987-2995

31. Toma JG, Akhavan M, Fernandes KJ, Barnabe-Heider F, Sadikot A, Kaplan DR, Miller FD 2001 Isolation of multipotent adult stem cells from the dermis of mammalian skin. Nat Cell Biol 3:778-784

32. Friedenstein AJ, Piatetzky-Shapiro II, Petrakova KV 1966 Osteogenesis in transplants of bone marrow cells. J Embryol Exp Morphol 16:381-390

33. Grigoriadis AE, Heersche JN, Aubin JE 1988 Differentiation of muscle, fat, cartilage, and bone from progenitor cells present in a bone-derived clonal cell population: effect of dexamethasone. J Cell Biol 106:2139-2151

34. Haynesworth SE, Goshima J, Goldberg VM, Caplan AI 1992 Characterization of cells with osteogenic potential from human marrow. Bone 13:81-88

35. Jaiswal N, Haynesworth SE, Caplan AI, Bruder SP 1997 Osteogenic differentiation of purified, culture-expanded human mesenchymal stem cells in vitro. J Cell Biochem 64:295-312

36. Johnstone B, Hering TM, Caplan AI, Goldberg VM, Yoo JU 1998 In vitro chondrogenesis of bone marrow-derived mesenchymal progenitor cells. Exp Cell Res 238:265-272

37. Pittenger MF, Mackay AM, Beck SC, Jaiswal RK, Douglas R, Mosca JD, Moorman MA, Simonetti DW, Craig S, Marshak DR 1999 Multilineage potential of adult human mesenchymal stem cells. Science 284:143-147

38. Wakitani S, Saito T, Caplan AI 1995 Myogenic cells derived from rat bone marrow mesenchymal stem cells exposed to 5-azacytidine. Muscle Nerve 18:1417-1426

39. George J, Kuboki Y, Miyata T 2006 Differentiation of mesenchymal stem cells into osteoblasts on honeycomb collagen scaffolds. Biotechnol Bioeng 95:404-411

40. Holtorf HL, Datta N, Jansen JA, Mikos AG 2005 Scaffold mesh size affects the osteoblastic differentiation of seeded marrow stromal cells cultured in a flow perfusion bioreactor. J Biomed Mater Res A 74:171-180

41. Okamoto M, Dohi Y, Ohgushi H, Shimaoka H, Ikeuchi M, Matsushima A, Yonemasu K, Hosoi H 2006 Influence of the porosity of hydroxyapatite ceramics on in vitro and in vivo bone formation by cultured rat bone marrow stromal cells. J Mater Sci Mater Med 17:327-336

42. Oliveira JM, Rodrigues MT, Silva SS, Malafaya PB, Gomes ME, Viegas CA, Dias IR, Azevedo JT, Mano JF, Reis RL 2006 Novel hydroxyapatite/chitosan bilayered scaffold for osteochondral tissue-engineering applications: scaffold design and its performance when seeded with goat bone marrow stromal cells. Biomaterials 27:6123-6137

43. Shih YR, Chen CN, Tsai SW, Wang YJ, Lee OK 2006 Growth of mesenchymal stem cells on electrospun type I collagen nanofibers. Stem Cells 24:2391-2397

44. Takahashi Y, Yamamoto M, Tabata Y 2005 Osteogenic differentiation of mesenchymal stem cells in biodegradable sponges composed of gelatin and betatricalcium phosphate. Biomaterials 26:3587-3596

45. Kon E, Muraglia A, Corsi A, Bianco P, Marcacci M, Martin I, Boyde A, Ruspantini I, Chistolini P, Rocca M, Giardino R, Cancedda R, Quarto R 2000 Autologous bone marrow stromal cells loaded onto porous hydroxyapatite ceramic accelerate bone repair in critical-size defects of sheep long bones. J Biomed Mater Res 49:328-337

46. Bruder SP, Kraus KH, Goldberg VM, Kadiyala S 1998 The effect of implants loaded with autologous mesenchymal stem cells on the healing of canine segmental bone defects. J Bone Joint Surg Am 80:985-996

47. Arinzeh TL, Peter SJ, Archambault MP, van den Bos C, Gordon S, Kraus K, Smith A, Kadiyala S 2003 Allogeneic mesenchymal stem cells regenerate bone in a critical-sized canine segmental defect. J Bone Joint Surg Am 85-A:1927-1935

48. Ohgushi H, Goldberg VM, Caplan AI 1989 Repair of bone defects with marrow cells and porous ceramic. Experiments in rats. Acta Orthop Scand 60:334-339

49. Ge Z, Baguenard S, Lim LY, Wee A, Khor E 2004 Hydroxyapatite-chitin materials as potential tissue engineered bone substitutes. Biomaterials 25:1049-1058

50. Jeong WK, Oh SH, Lee JH, Im GI 2008 Repair of osteochondral defect with a construct of mesenchymal stem cells and polydioxanone/polyvinyl alcohol scaffold. Biotechnol Appl Biochem 49:155-164

51. Shao X, Goh JC, Hutmacher DW, Lee EH, Zigang G 2006 Repair of large articular osteochondral defects using hybrid scaffolds and bone marrow-derived mesenchymal stem cells in a rabbit model. Tissue Eng 12:1539-1551

52. Meinel L, Fajardo R, Hofmann S, Langer R, Chen J, Snyder B, Vunjak-Novakovic G, Kaplan D 2005 Silk implants for the healing of critical size bone defects. Bone 37:688-698

53. Zuk PA, Zhu M, Ashjian P, De Ugarte DA, Huang JI, Mizuno H, Alfonso ZC, Fraser JK, Benhaim P, Hedrick MH 2002 Human adipose tissue is a source of multipotent stem cells. Mol Biol Cell 13:4279-4295
54. Zuk PA, Zhu M, Mizuno H, Huang J, Futrell JW, Katz AJ, Benhaim P, Lorenz HP, Hedrick MH 2001 Multilineage cells from human adipose tissue: implications for cell-based therapies. Tissue Eng 7:211-228

55. Rodbell M 1964 Metabolism of isolated fat cells. J Biol Chem 239:375-380

56. Hauner H, Entenmann G, Wabitsch M, Gaillard D, Ailhaud G, Negrel R, Pfeiffer EF 1989 Promoting effect of glucocorticoids on the differentiation of human adipocyte precursor cells cultured in a chemically defined medium. J Clin Invest $84: 1663-1670$

57. Gimble JM, Katz AJ, Bunnell BA 2007 Adipose-derived stem cells for regenerative medicine. Circ Res 100:1249-1260

58. Zheng B, Cao B, Li G, Huard J 2006 Mouse adipose-derived stem cells undergo multilineage differentiation in vitro but primarily osteogenic and chondrogenic differentiation in vivo. Tissue Eng 12:1891-1901

59. Zhang X, Yang M, Lin L, Chen P, Ma KT, Zhou CY, Ao YF 2006 Runx2 overexpression enhances osteoblastic differentiation and mineralization in adiposederived stem cells in vitro and in vivo. Calcif Tissue Int 79:169-178

60. Yang M, Ma QJ, Dang GT, Ma K, Chen P, Zhou CY 2005 In vitro and in vivo induction of bone formation based on ex vivo gene therapy using rat adiposederived adult stem cells expressing BMP-7. Cytotherapy 7:273-281

61. Yang LY, Liu XM, Sun B, Hui GZ, Fei J, Guo LH 2004 Adipose tissue-derived stromal cells express neuronal phenotypes. Chin Med J (Engl) 117:425-429

62. Winter A, Breit S, Parsch D, Benz K, Steck E, Hauner H, Weber RM, Ewerbeck V, Richter W 2003 Cartilage-like gene expression in differentiated human stem cell spheroids: a comparison of bone marrow-derived and adipose tissue-derived stromal cells. Arthritis Rheum 48:418-429

63. Timper K, Seboek D, Eberhardt M, Linscheid P, Christ-Crain M, Keller U, Muller B, Zulewski H 2006 Human adipose tissue-derived mesenchymal stem cells differentiate into insulin, somatostatin, and glucagon expressing cells. Biochem Biophys Res Commun 341:1135-1140

64. Tholpady SS, Katz AJ, Ogle RC 2003 Mesenchymal stem cells from rat visceral fat exhibit multipotential differentiation in vitro. Anat Rec A Discov Mol Cell Evol Biol 272:398-402

65. Seo MJ, Suh SY, Bae YC, Jung JS 2005 Differentiation of human adipose stromal cells into hepatic lineage in vitro and in vivo. Biochem Biophys Res Commun 328:258-264

66. Safford KM, Safford SD, Gimble JM, Shetty AK, Rice HE 2004 Characterization of neuronal/glial differentiation of murine adipose-derived adult stromal cells. Exp Neurol 187:319-328

67. Safford KM, Hicok KC, Safford SD, Halvorsen YD, Wilkison WO, Gimble JM, Rice HE 2002 Neurogenic differentiation of murine and human adipose-derived stromal cells. Biochem Biophys Res Commun 294:371-379

68. Planat-Benard V, Silvestre JS, Cousin B, Andre M, Nibbelink M, Tamarat R, Clergue M, Manneville C, Saillan-Barreau C, Duriez M, Tedgui A, Levy B, Penicaud L, Casteilla L 2004 Plasticity of human adipose lineage cells toward endothelial cells: physiological and therapeutic perspectives. Circulation 109:656663

69. Planat-Benard V, Menard C, Andre M, Puceat M, Perez A, Garcia-Verdugo JM, Penicaud L, Casteilla L 2004 Spontaneous cardiomyocyte differentiation from adipose tissue stroma cells. Circ Res 94:223-229

70. Ogawa R, Mizuno H, Hyakusoku H, Watanabe A, Migita M, Shimada T 2004 Chondrogenic and osteogenic differentiation of adipose-derived stem cells isolated from GFP transgenic mice. J Nippon Med Sch 71:240-241

71. Morizono K, De Ugarte DA, Zhu M, Zuk P, Elbarbary A, Ashjian P, Benhaim P, Chen IS, Hedrick MH 2003 Multilineage cells from adipose tissue as gene delivery vehicles. Hum Gene Ther 14:59-66

72. Mizuno H, Hyakusoku H 2003 Mesengenic potential and future clinical perspective of human processed lipoaspirate cells. J Nippon Med Sch 70:300-306

73. Kokai LE, Rubin JP, Marra KG 2005 The potential of adipose-derived adult stem cells as a source of neuronal progenitor cells. Plast Reconstr Surg 116:1453-1460

74. Kang SK, Putnam LA, Ylostalo J, Popescu IR, Dufour J, Belousov A, Bunnell BA 2004 Neurogenesis of Rhesus adipose stromal cells. J Cell Sci 117:4289-4299

75. Huang JI, Zuk PA, Jones NF, Zhu M, Lorenz HP, Hedrick MH, Benhaim P 2004 Chondrogenic potential of multipotential cells from human adipose tissue. Plast Reconstr Surg 113:585-594

76. Guilak F, Lott KE, Awad HA, Cao Q, Hicok KC, Fermor B, Gimble JM 2006 Clonal analysis of the differentiation potential of human adipose-derived adult stem cells. J Cell Physiol 206:229-237

77. Gimble JM, Guilak F 2003 Differentiation potential of adipose derived adult stem (ADAS) cells. Curr Top Dev Biol 58:137-160

78. Fraser JK, Schreiber RE, Zuk PA, Hedrick MH 2004 Adult stem cell therapy for the heart. Int J Biochem Cell Biol 36:658-666

79. Ashjian PH, Elbarbary AS, Edmonds B, DeUgarte DA, Zhu M, Zuk PA, Lorenz HP, Benhaim P, Hedrick MH 2003 In vitro differentiation of human processed lipoaspirate cells into early neural progenitors. Plast Reconstr Surg 111:1922-1931

80. Jack GS, Almeida FG, Zhang R, Alfonso ZC, Zuk PA, Rodriguez LV 2005 Processed lipoaspirate cells for tissue engineering of the lower urinary tract: implications for the treatment of stress urinary incontinence and bladder reconstruction. J Urol 174:2041-2045

81. Mizuno H, Zuk PA, Zhu M, Lorenz HP, Benhaim P, Hedrick MH 2002 Myogenic differentiation of human processed lipoaspirate cells. Plast Reconstr Surg 109:199_ 209

82. Nakagami H, Morishita R, Maeda K, Kikuchi Y, Ogihara T, Kaneda Y 2006 Adipose tissue-derived stromal cells as a novel option for regenerative cell therapy. J Atheroscler Thromb 13:77-81 
83. Schaffler A, Buchler C 2007 Concise review: adipose tissue-derived stromal cells-basic and clinical implications for novel cell-based therapies. Stem Cells 25:818-827

84. Casteilla L, Dani C 2006 Adipose tissue-derived cells: from physiology to regenerative medicine. Diabetes Metab 32:393-401

85. Helder MN, Knippenberg M, Klein-Nulend J, Wuisman PI 2007 Stem cells from adipose tissue allow challenging new concepts for regenerative medicine. Tissue Eng 13:1799-1808

86. Hicok KC, Du Laney TV, Zhou YS, Halvorsen YD, Hitt DC, Cooper LF, Gimble JM 2004 Human adipose-derived adult stem cells produce osteoid in vivo. Tissue Eng 10:371-380

87. Lee JA, Parrett BM, Conejero JA, Laser J, Chen J, Kogon AJ, Nanda D, Grant RT, Breitbart AS 2003 Biological alchemy: engineering bone and fat from fat-derived stem cells. Ann Plast Surg 50:610-617

88. Dragoo JL, Choi JY, Lieberman JR, Huang J, Zuk PA, Zhang J, Hedrick MH, Benhaim P 2003 Bone induction by BMP-2 transduced stem cells derived from human fat. J Orthop Res 21:622-629

89. Dragoo JL, Lieberman JR, Lee RS, Deugarte DA, Lee Y, Zuk PA, Hedrick MH, Benhaim P 2005 Tissue-engineered bone from BMP-2-transduced stem cells derived from human fat. Plast Reconstr Surg 115:1665-1673

90. Hattori H, Masuoka K, Sato M, Ishihara M, Asazuma T, Takase B, Kikuchi M, Nemoto K, Ishihara M 2005 Bone formation using human adipose tissue-derived stromal cells and a biodegradable scaffold. J Biomed Mater Res B Appl Biomater 76:230-239

91. Peterson B, Zhang J, Iglesias R, Kabo M, Hedrick M, Benhaim P, Lieberman JR 2005 Healing of critically sized femoral defects, using genetically modified mesenchymal stem cells from human adipose tissue. Tissue Eng 11:120-129

92. Chang SC, Chuang H, Chen YR, Yang LC, Chen JK, Mardini S, Chung HY, Lu YL, Ma WC, Lou J 2004 Cranial repair using BMP-2 gene engineered bone marrow stromal cells. J Surg Res 119:85-91

93. Lieberman JR, Daluiski A, Stevenson S, Wu L, McAllister P, Lee YP, Kabo JM, Finerman GA, Berk AJ, Witte ON 1999 The effect of regional gene therapy with bone morphogenetic protein-2-producing bone-marrow cells on the repair of segmental femoral defects in rats. J Bone Joint Surg Am 81:905-917

94. Tsuda H, Wada T, Yamashita T, Hamada H 2005 Enhanced osteoinduction by mesenchymal stem cells transfected with a fiber-mutant adenoviral BMP2 gene. J Gene Med 7:1322-1334

95. De Kok IJ, Peter SJ, Archambault M, van den Bos C, Kadiyala S, Aukhil I, Cooper LF 2003 Investigation of allogeneic mesenchymal stem cell-based alveolar bone formation: preliminary findings. Clin Oral Implants Res 14:481-489

96. Mankani MH, Kuznetsov SA, Wolfe RM, Marshall GW, Robey PG 2006 In vivo bone formation by human bone marrow stromal cells: reconstruction of the mouse calvarium and mandible. Stem Cells 24:2140-2149

97. Krebsbach PH, Mankani MH, Satomura K, Kuznetsov SA, Robey PG 1998 Repair of craniotomy defects using bone marrow stromal cells. Transplantation 66:12721278

98. Bidic SM, Calvert JW, Marra K, Kumta P, Campbell P, Mitchell R, Wigginton W, Hollinger JO, Weiss L, Mooney MP 2003 Rabbit calvarial wound healing by means of seeded Caprotite scaffolds. J Dent Res 82:131-135

99. Radice M, Brun P, Cortivo R, Scapinelli R, Battaliard C, Abatangelo G 2000 Hyaluronan-based biopolymers as delivery vehicles for bone-marrow-derived mesenchymal progenitors. J Biomed Mater Res 50:101-109

100. Weng Y, Wang M, Liu W, Hu X, Chai G, Yan Q, Zhu L, Cui L, Cao Y 2006 Repair of experimental alveolar bone defects by tissue-engineered bone. Tissue Eng 12:1503-1513

101. Shang Q, Wang Z, Liu W, Shi Y, Cui L, Cao Y 2001 Tissue-engineered bone repair of sheep cranial defects with autologous bone marrow stromal cells. J Craniofac Surg 12:586-593

102. Kraut RA 1987 The use of allogeneic bone for alveolar cleft grafting. Oral Surg Oral Med Oral Pathol 64:278-282

103. Hibi H, Yamada Y, Ueda M, Endo Y 2006 Alveolar cleft osteoplasty using tissue-engineered osteogenic material. Int J Oral Maxillofac Surg 35:551-555

104. Kadiyala S, Young RG, Thiede MA, Bruder SP 1997 Culture expanded canine mesenchymal stem cells possess osteochondrogenic potential in vivo and in vitro. Cell Transplant 6:125-134

105. Baumann A, Ewers R 2000 Application of the buccal fat pad in oral reconstruction. J Oral Maxillofac Surg 58:389-392; discussion 392-393

106. Hudson JW, Anderson JG, Russell RM Jr, Anderson N, Chambers K 1995 Use of pedicled fat pad graft as an adjunct in the reconstruction of palatal cleft defects. Oral Surg Oral Med Oral Pathol Oral Radiol Endod 80:24-27

107. Dudas JR, Marra KG, Cooper GM, Penascino VM, Mooney MP, Jiang S, Rubin JP, Losee JE 2006 The osteogenic potential of adipose-derived stem cells for the repair of rabbit calvarial defects. Ann Plast Surg 56:543-548

108. Yoon E, Dhar S, Chun DE, Gharibjanian NA, Evans GR 2007 In vivo osteogenic potential of human adipose-derived stem cells/poly lactide-co-glycolic acid constructs for bone regeneration in a rat critical-sized calvarial defect model. Tissue Eng 13:619-627

109. Mauney JR, Nouyen T, Gillen K, Kirker-Head C, Gimble JM, Kaplan DL 2007 Engineering adipose-like tissue in vitro and in vivo utilizing human bone marrow and adipose-derived mesenchymal stem cells with silk fibroin 3D scaffolds. Biomaterials 28:5280-5290

110. Cui L, Liu B, Liu G, Zhang W, Cen L, Sun J, Yin S, Liu W, Cao Y 2007 Repair of cranial bone defects with adipose derived stem cells and coral scaffold in a canine model. Biomaterials 28:5477-5486
111. Follmar KE, Prichard HL, DeCroos FC, Wang HT, Levin LS, Klitzman B, Olbrich KC, Erdmann D 2007 Combined bone allograft and adipose-derived stem cell autograft in a rabbit model. Ann Plast Surg 58:561-565

112. Erfani S, Maldonado TS, Crisera CA, Warren SM, Lee S, Longaker MT 2001 An in vitro mouse model of cleft palate: defining a critical intershelf distance necessary for palatal clefting. Plast Reconstr Surg 108:403-410

113. Resel E, Martinez-Sanz E, Gonzalez I, Trinidad E, Garcillan B, Amoros M, Alonso-Banuelos C, Gonzalez-Meli B, Lagaron E, Murillo J, Del Rio A, Barrio C, Lopez M, Martinez-Alvarez C 2007 In vitro manipulation of cleft palate connective tissue: setting the bases of a proposed new treatment. J Surg Res 138:111-120

114. Carstanjen B, Desbois C, Hekmati M, Behr L 2006 Successful engraftment of cultured autologous mesenchymal stem cells in a surgically repaired soft palate defect in an adult horse. Can J Vet Res 70:143-147

115. Akita S, Fukui M, Nakagawa H, Fujii T, Akino K 2004 Cranial bone defect healing is accelerated by mesenchymal stem cells induced by coadministration of bone morphogenetic protein-2 and basic fibroblast growth factor. Wound Repair Regen 12:252-259

116. Noel D, Gazit D, Bouquet C, Apparailly F, Bony C, Plence P, Millet V, Turgeman G, Perricaudet M, Sany J, Jorgensen C 2004 Short-term BMP-2 expression is sufficient for in vivo osteochondral differentiation of mesenchymal stem cells. Stem Cells 22:74-85

117. Tang TT, Xu XL, Dai KR, Yu CF, Yue B, Lou JR 2005 Ectopic bone formation of human bone morphogenetic protein-2 gene transfected goat bone marrow-derived mesenchymal stem cells in nude mice. Chin J Traumatol 8:3-7

118. Zachos TA, Shields KM, Bertone AL 2006 Gene-mediated osteogenic differentiation of stem cells by bone morphogenetic proteins-2 or -6. J Orthop Res 24:12791291

119. Diefenderfer DL, Osyczka AM, Reilly GC, Leboy PS 2003 BMP responsiveness in human mesenchymal stem cells. Connect Tissue Res 44:305-311

120. Osyczka AM, Diefenderfer DL, Bhargave G, Leboy PS 2004 Different effects of BMP-2 on marrow stromal cells from human and rat bone. Cells Tissues Organs 176:109-119

121. Einhorn TA 2003 Clinical applications of recombinant human BMPs: early experience and future development. J Bone Joint Surg Am 85-A:82-88

122. Fujibayashi S, Neo M, Kim HM, Kokubo T, Nakamura T 2003 A comparative study between in vivo bone ingrowth and in vitro apatite formation on $\mathrm{Na}_{2} \mathrm{O}-\mathrm{CaO}$ $\mathrm{SiO}_{2}$ glasses. Biomaterials 24:1349-1356

123. Kokubo T, Ito S, Huang ZT, Hayashi T, Sakka S, Kitsugi T, Yamamuro T 1990 Ca, P-rich layer formed on high-strength bioactive glass-ceramic A-W. J Biomed Mater Res 24:331-343

124. Kokubo T, Hanakawa M, Kawashita M, Minoda M, Beppu T, Miyamoto T, Nakamura T 2004 Apatite formation on non-woven fabric of carboxymethylated chitin in SBF. Biomaterials 25:4485-4488

125. Chou YF, Chiou WA, Xu Y, Dunn JC, Wu BM 2004 The effect of pH on the structural evolution of accelerated biomimetic apatite. Biomaterials 25:5323-5331

126. Chou YF, Huang W, Dunn JC, Miller TA, Wu BM 2005 The effect of biomimetic apatite structure on osteoblast viability, proliferation, and gene expression. Biomaterials 26:285-295

127. Chou YF, Dunn JC, Wu BM 2005 In vitro response of MC3T3-E1 pre-osteoblasts within three-dimensional apatite-coated PLGA scaffolds. J Biomed Mater Res B Appl Biomater 75:81-90

128. Cowan CM, Shi YY, Aalami OO, Chou YF, Mari C, Thomas R, Quarto N, Contag $\mathrm{CH}, \mathrm{Wu}$ B, Longaker MT 2004 Adipose-derived adult stromal cells heal criticalsize mouse calvarial defects. Nat Biotechnol 22:560-567

129. Gori F, Thomas T, Hicok KC, Spelsberg TC, Riggs BL 1999 Differentiation of human marrow stromal precursor cells: bone morphogenetic protein-2 increases OSF2/CBFA1, enhances osteoblast commitment, and inhibits late adipocyte maturation. J Bone Miner Res 14:1522-1535

130. Lou J, Tu Y, Li S, Manske PR 2000 Involvement of ERK in BMP-2 induced osteoblastic differentiation of mesenchymal progenitor cell line C3H10T1/2. Biochem Biophys Res Commun 268:757-762

131. Noth U, Tuli R, Seghatoleslami R, Howard M, Shah A, Hall DJ, Hickok NJ, Tuan RS 2003 Activation of p38 and Smads mediates BMP-2 effects on human trabecular bone-derived osteoblasts. Exp Cell Res 291:201-211

132. Jaiswal RK, Jaiswal N, Bruder SP, Mbalaviele G, Marshak DR, Pittenger MF 2000 Adult human mesenchymal stem cell differentiation to the osteogenic or adipogenic lineage is regulated by mitogen-activated protein kinase. J Biol Chem 275:96459652

133. Bost F, Aouadi M, Caron L, Even P, Belmonte N, Prot M, Dani C, Hofman P, Pages G, Pouyssegur J, Le Marchand-Brustel Y, Binetruy B 2005 The extracellular signal-regulated kinase isoform ERK1 is specifically required for in vitro and in vivo adipogenesis. Diabetes 54:402-411

134. Jeon ES, Kang YJ, Song HY, Woo JS, Jung JS, Kim YK, Kim JH 2005 Role of MEK-ERK pathway in sphingosylphosphorylcholine-induced cell death in human adipose tissue-derived mesenchymal stem cells. Biochim Biophys Acta $1734: 25-33$

135. Kang YJ, Jeon ES, Song HY, Woo JS, Jung JS, Kim YK, Kim JH 2005 Role of c-Jun N-terminal kinase in the PDGF-induced proliferation and migration of human adipose tissue-derived mesenchymal stem cells. J Cell Biochem 95:1135-1145

136. Edwards PC, Ruggiero S, Fantasia J, Burakoff R, Moorji SM, Paric E, Razzano P, Grande DA, Mason JM 2005 Sonic hedgehog gene-enhanced tissue engineering for bone regeneration. Gene Ther 12:75-86

137. Parr BA, McMahon AP 1994 Wnt genes and vertebrate development. Curr Opin Genet Dev 4:523-528

138. Gong Y, Slee RB, Fukai N, Rawadi G, Roman-Roman S, Reginato AM, Wang H, Cundy T, Glorieux FH, Lev D, Zacharin M, Oexle K, Marcelino J, Suwairi W, 
Heeger S, Sabatakos G, Apte S, Adkins WN, Allgrove J, Arslan-Kirchner M, Batch JA, Beighton P, Black GC, Boles RG, Boon LM, Borrone C, Brunner HG, Carle GF, Dallapiccola B, De Paepe A, Floege B, Halfhide ML, Hall B, Hennekam RC, Hirose T, Jans A, Juppner H, Kim CA, Keppler-Noreuil K, Kohlschuetter A, LaCombe D, Lambert M, Lemyre E, Letteboer T, Peltonen L, Ramesar RS, Romanengo M, Somer H, Steichen-Gersdorf E, Steinmann B, Sullivan B, SupertiFurga A, Swoboda W, van den Boogaard MJ, Van Hul W, Vikkula M, Votruba M, Zabel B, Garcia T, Baron R, Olsen BR, Warman ML 2001 LDL receptor-related protein 5 (LRP5) affects bone accrual and eye development. Cell 107:513-523

139. Boland GM, Perkins G, Hall DJ, Tuan RS 2004 Wnt 3a promotes proliferation and suppresses osteogenic differentiation of adult human mesenchymal stem cells. J Cell Biochem 93:1210-1230

140. Chang J, Sonoyama W, Wang Z, Jin Q, Zhang C, Krebsbach PH, Giannobile W, Shi S, Wang CY 2007 Noncanonical Wnt-4 signaling enhances bone regeneration of mesenchymal stem cells in craniofacial defects through activation of p38 MAPK. J Biol Chem 282:30938-30948
141. Singh S, Yin X, Pisano MM, Greene RM 2007 Molecular profiles of mitogen activated protein kinase signaling pathways in orofacial development. Birth Defects Res A Clin Mol Teratol 79:35-44

142. Kundu AK, Putnam AJ 2006 Vitronectin and collagen I differentially regulate osteogenesis in mesenchymal stem cells. Biochem Biophys Res Commun 347:347357

143. Globus RK, Moursi A, Zimmerman D, Lull J, Damsky C 1995 Integrinextracellular matrix interactions in connective tissue remodeling and osteoblast differentiation. ASGSB Bull 8:19-28

144. Xiao G, Wang D, Benson MD, Karsenty G, Franceschi RT 1998 Role of the alpha2-integrin in osteoblast-specific gene expression and activation of the Osf2 transcription factor. J Biol Chem 273:32988-32994

145. Chen Q, Kinch MS, Lin TH, Burridge K, Juliano RL 1994 Integrin-mediated cell adhesion activates mitogen-activated protein kinases. J Biol Chem 269:2660226605 